\title{
From Flasks to Fine Glasses: Recent Trends in Wine Economics
}

\section{Anna Carbone $^{1}$ (D)}

Received: 8 January 2021 / Accepted: 28 February 2021 / Published online: 11 March 2021

(c) Società Italiana di Economia (Italian Economic Association) 2021

\begin{abstract}
This short literature review on wine economics introduces the Special Issue on wine of the Italian Economic Journal. Its goal is to provide non wine experts with an overall picture of recent trends of the wine sector and of major developments of the economic literature devoted to wine markets. As the wine market deeply changed through the last decades, the first section quickly outlines these changes. The second section revise literature on wine demand while the third section is on supply and the fourth is focused on policies.
\end{abstract}

Keywords Wine $\cdot$ Supply $\cdot$ Demand $\cdot$ Policies

JEL Classification Q11·Q13·Q18

\section{Introduction}

The wine industry has changed dramatically in the last decades with an acceleration of change since the turn of the century onwards (Bargain et al. 2018; Unwin 2005). On the demand side, things have immensely changed as wine, once included in the everyday diet as a basic source of energy especially for peasants, farmers and working-class people, is now a hedonic good basically consumed in free time and in social occasions and with strong status symbol implications (Charters and Pettigrew 2008; Thach 2012). Wine is no more a slightly differentiated good often traded as a bulk commodity; wine is luxury; wine is cool and fashion. Especially in high income countries and/or higher income population groups, attributes related to culture, traditions, emotions, tourism and discovery, experience of novelty, selfidentity, signalling of social status and so forth, contribute to motivations for purchase and consumption in addition to sensory features (Carlsen and Boksberger

Anna Carbone

acarbone@unitus.it

1 DIBAF-Department for Innovation in Biological, Agro-Food and Forest Systems, Università Della Tuscia, Viterbo, Italy 
2015; Mouret et al. 2013; Thach, 2012). Everywhere market segmentation is very pronounced. These aspects of wine demand are partly associated to the entry in the market of consumers living in countries where wine was not a traditional alcoholic beverage and it is now somehow regarded as a new exotic and trendy good connected to the general idea of the French savoir vivre and/or to the Italian style. In these countries per capita consumption of wine is rapidly increasing. Differently, in traditional producing/consuming countries the globalization wave leads consumers to drink less wine and more beer and spirits than in previous times. Here, per capita consumption follows a pronounced negative long run trend, like in Italy where figures dropped from more than $100 \mathrm{~kg}$ in the sixties to less than $40 \mathrm{~kg}$ in present years (Pomarici et al. 2021; Carbone et al. 2019; Lesschaeve 2007).

Furthermore, nowadays wine is no more only bought to be consumed: as in some cases its value increases with time, wine can be bought and kept just as other kind of investments and happens to be a somehow close substitute, not of beer and spirits as one may think, but rather as an alternative to art masterpieces or to other financial assets in portfolio diversification strategies (Masset and Henderson 2010).

The supply side also changed under the pressure of different forces. Many efforts have been devoted to a general quality upgrade and product differentiation in order to better meet demand. These have led to one of the most complex agri-food industries and one of the most sophisticated agri-food products. Production technology, though not much, has also evolved both in the vineyard and in the winery so that the whole process has changed. Cultivated grapes changed, with a substantial reduction in the number of varieties and the diffusion of a small number of ubiquity vines spread up all over. The wine itself has changed, not only due to the different grapes used for making wine but also thanks to a greater attention to quality and diversification as in the case of sustainable, organic, biodinamic, ethic attributes, just to make a few examples.

Grape production remains highly fragmented, especially in some countries, however, grape growers and wine producers did change from small households only partially market-oriented to larger specialized companies better embedded in (often global) value chains. The downstream stages of the value chain underwent a significant concentration process. The retail sector increased its average size and internal complexity and it has now in its hands the governance of some relevant upstream stages of the value chain (Folwell and Volanti 2003; Gwynne 2008). Furthermore, new actors entered in the scene such as wine technicians, oenologist, wine experts and wine journalists and communicators, and so on. These are all basically related to process management, quality improvements, process and product certification, communication and promotion (Hommerberg 2011). The experience and/or credence nature of wine attributes that are increasingly more relevant are at the basis of the strong need for providing information and quality guarantees along the chains as well as to the final consumer (Sherman and Tuten 2011).

New countries entered the industry also on the supply side. These are generally referred to as the New Wine World (NWW) - a group of countries scattered in different continents - as opposed to the Old Wine World (OWW) that refers to European producer countries (Bargain et al. 2018). There has also been a general shift towards former cooler places warmed-up by climate change. 


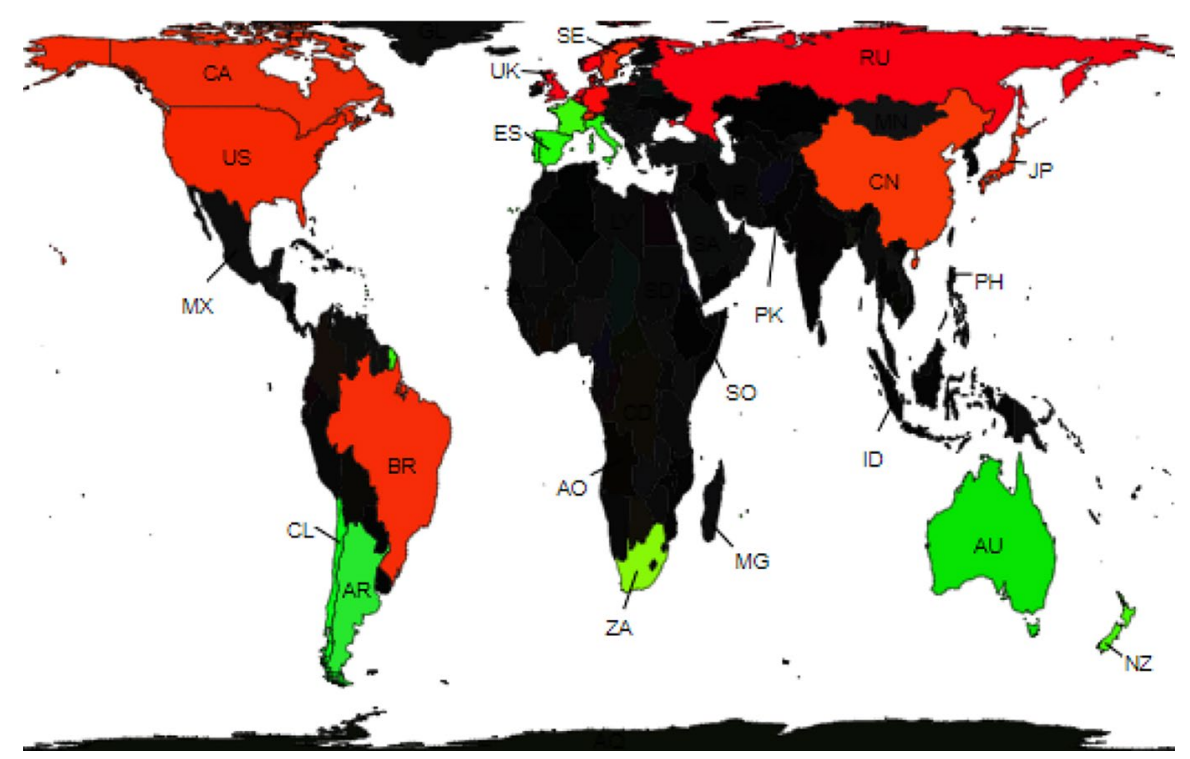

Fig. 1 The world geography of wine trade

Figure 1 shows the map of world major wine traders. Countries in red are net importers while countries in green are net exporters; among these the European ones are OWW countries while the remaining ones plus USA (in red because, despite being an important world exporter is a net wine importer) form the NWW group.

Thus, the new and wider geography of the wine industry relates to both demand and supply. This leads to a significant globalisation of the wine industry as a multifaceted phenomenon that encompasses a variety of features among which it is worth to recall: (i) demand globalisation and the diffusion of the so-called international grape varieties, also accompanied by the opposite trend of rediscovery of traditional local varieties; (ii) the "migration" of wine experts from OWW to NWW for disseminating traditional know-how and informal knowledge (Giuliani et al. 2011); (iii) foreign direct investments (together with other financial operations) of large companies (both within the sector and from other sectors) seeking at diversifying their portfolio, their production base, locations and/or activities (Giuliani et al. 2011); (iv) increased and re-shaped wine trade flows (Unwin 2005). As for trade flows, these changed, under the influence of the changes in supply and demand, in many regards and especially in quantities, values, diversification, and countries involved, including an increase of intra-industry trade (Carbone et al. 2021).

The rising interest around wine is also witnessed by the vast number of magazines, journals, TV shows, blogs, fairs and prizes that flourished all around the world. This growing interest of the public is paired by the greater attention that specialists and scientists in different fields devote to wine. This is true also in the field of economics and has led to many new specialized journals as well as to many articles about wine being published in general economics reviews just as the Special Issue hosted by the Italian Economic Journal (Vol. 7, Issue 2, 2021). The topics 
covered by this large stream of literature are manifold and form a heterogeneous body of contributions with respect to the underling theoretical paradigm and methodological approaches adopted. In the following pages I present a review of recent developments in wine markets as seen through the main contributions of the wine economic literature. The review focuses on some of the main strands of the recent literature developed by wine economists with no ambition of being exhaustive as this would be far beyond the scope and length of this article.

\section{The Demand Side}

In recent years, the analysis of wine demand and consumers' behavior expanded enormously, with many bodies of literature crossing and cross-fertilizing each other. In particular, studies on consumers' willingness to pay for different product attributes and on consumers' attitudes, behavior and choice flourished (Galati et al. 2020). As wine has become a hedonic and highly differentiated good, the influence of quality in market functioning and in firms' strategies, together with market segmentation, attract a big deal of attention in economic literature. In the last decade or so there has been a huge number of studies that apply the hedonic price model (HPM) introduced by Rosen (1974) to the wine market. The equations estimated in such works are much diversified, going from focusing on the price elasticity of grape varieties, alcohol content, vintages, ratings obtained by experts, on the market values for organic wines, for the different Geographical Indications (GIs), for different wine's and producer's typologies, label information, brand, etc. (Unwin 1999; Caracciolo et al. 2013; Carbone et al. 2014; Nerlove 1995; Oczkowski 1994; Schamel and Ros 2021). One interesting result of HPMs concerns the European wine GI system for which it is highlighted that the officially established quality pyramid is partly reversed in the market by wines with Protected Geographical Indication (PGI). In fact, PGI wines often get higher price premiums than the ones with the Protected Designation of Origin (PDO) that should, in principle, benefit from the higher level of their quality certification (Cacchiarelli et al. 2016). Results provided by different estimations of the HPMs are not always aligned as they depend strictly on the wines included and on the kind and source of data used, thus confirming the deep segmentation of the market with the different segments that quite often act in idiosyncratic ways (Costanigro et al. 2007). One key controversial point concerns the relationship between experts' ratings (i.e. assessed quality) and actual prices. Many of the cited studies find that prices are influenced by very many attributesincluding sensorial as well as extrinsic features. Some of them affirm that qualityas assessed and ranked by expert s- can be, in turn, influenced by prices. Differently, Combris et al. (1997) find that assessed quality only depends on sensory attributes. I The major limitation of the HPM is that it assumes that estimated prices are market equilibrium prices. This implies that when consumers and/or producers look at empirical results they must keep in mind that prices, and thus attributed values, may change following their own behaviors, especially if they are large agents compared to the overall size of the market segment in which they operate (Oczkowski 1994). 
In connection with the role of product differentiation and of quality, increasing attention is paid to analyzing consumers' preferences and attitude towards wine, in relation to age, gender and other personal features. This includes the analysis of places of consumption, as house consumption generally involves buying in different shops and drinking different wines compared to off-house consuming occasions (Thach 2012; Hall et al. 2004). This also encompasses the many connections between wine purchase and consumption, on the one side, and tourism, on the other side (Pelegrín-Borondo et al. 2020). More in details, the strict connections between wine tourism and the search of typical products, the discovery of local cultural heritages and the desire for novelty and ethnic experiences are explored (Borondo et al. 2020). In general, the emotional sphere associated to buying and consuming behaviors forms a separate and additional theme of analysis that helps producers, experts in marketing and market analysists in understanding better consumers' choice, behavior and satisfaction (Calvo-Porral et al. 2020; Danner et al. 2016).

Wine literature also devotes a great deal of attention to the influence of experts' ratings on wine reputation and on consumers' choice and willingness to pay. Indeed, experts' evaluations have such a deep influence on the market that they can be considered as a further factor of market segmentation. More recent contributions tend to acknowledge differences in experts' ratings not any more as an "accident" to be explained as an error linked to subjectivity or to the variability of the trials settings but rather as a desirable, or even necessary, mirror of the existence of different preferences and tastes among people. As a consequence, a market of expert's evaluations (i.e. expert guides, websites, magazines, and the like), able to orient the wine market, arose. This is the reason why the so-called Ashenfelter Eq. (Ashenfelter et al. 1995) - that has proven to be reliable in predicting the quality of a vintage based on freely available weather data-remains basically neglected by the wider public who prefers to rely on the somehow "exciting, enticing and mystic", but more effective, storytelling approach of wine "gurus" such as Wine Spectator, Wine Advocate or Wine Enthusiast, just to cite a few among the most impacting ones (Hommerberg 2011). Successful oenologysts do not limit themselves to advice wineries on the production process, like it used to be in the past, they tend to be true deus-ex-machina of the market giving also key inputs to the creative process of conceiving new wines and to promoting them, not only to the final consumers (i.e. through articles, interviews, etc.) but also to all the many actors populating the complex supply chain and the distribution sector. ${ }^{1}$

\footnotetext{
${ }^{1}$ In particular, in the jargon of the wine sector "flying winemakers" are professionals, often oenologysts, with great expertise and experience who share their knowledge with wineries across the globe usually for one or few vintages. They supervise the whole production process, usually collaborating with the winery in creating new original wines. This allows wineries to benefit from top experts' competences on viticulture, winemaking technology and market trends without long term commitments.
} 


\section{The Supply Side}

In a situation in which the role of the retail sector in shaping production and consumption is definitely increasing, wine economists are also engaging themselves with the global value chain dimension of the sector (Gwynne 2008). Their goal is to understand to what extent efficiency and competitiveness of grape growers and of wineries are related to being embedded in global supply chains and at what conditions they can upgrade their positioning along these chains. One interesting example is provided by the Chilean experience (Gwynne 2008) that shows how producers managed to insert themselves in wine global value chains thanks to cultural, technological and managerial upgrade also in relation to the role of flying winemakers. One key element of this successful upgrade has been the capacity of the Chilean producers to form wine associations essentially with the scope of establishing relations with wine critics and journalists, scholars and experts and gaining visibility in trade journals and wine websites. This is a vehicle for raising their reputation, especially abroad, and for rapid export growth; it helped producers to become suppliers of large retailers in different countries and in establishing significant amounts of bargaining power within the value chain. The increased bargaining power of producers helps when negotiating prices but also when deciding about the shelf allocation of bottles (an increasingly crucial aspect for capturing consumers' attention).

The South African wine sector tells a different story (Ponte and Ewert 2009) in which improving the production process, upgrading quality and enhancing the overall organization efficiency did not prove to be able to bring an upgrade of South African wineries along the global value chains. The authors find reasons for this outcome in a set of concurring factors such as the increasing demand for basic quality and bulk wines; the need for shorter lead times; the need of more flexibility in deliveries according to buyer specifications; significant casualization of labor (i.e. temporary and/or part-time jobs and subcontracted workers); and the request to participate to the costs for promotional activities of the retailer. The results are as follows: low visibility of producers in the final markets; their poor bargaining power and low margins. In this context, product downgrading may be the only options for keeping market shares. In particular, for South African wineries this has been considered the best option available, at least in the short run (Ponte and Ewert 2009). ${ }^{2}$

This theme is partly connected with the study of the changing patterns of international trade and of countries' competitive advantages. Wine trade has more than doubled from the early Nineties to the first decade of the new century, encompassing an increasing number of countries and reaching a share of more than $30 \%$ of total world production (Mariani et al. 2012; Pomarici et al. 2012). In the meanwhile, consuming, producing, importing and exporting countries have changed, completely transforming the world geography of wine (Carbone et al. 2019).

Supply analysis has recently been also focused on the study of the environmental impact of production and on the impact of climate change on production. These

\footnotetext{
${ }^{2}$ For a different approach to the supply chain analysis see the contribution of Romano et al. (2021) that provides original insights about frauds in the wine sector.
} 
include the relationship between viticulture and climate change, together with the analysis of the climatic determinants of changes in the geography of wine production. Climate change encompasses the increase in average temperature and changes in rain frequencies and in their seasonal patterns, but it also includes weather variability favoring extreme events (Storchmann 2012). All these phenomena have various and non-fixed impacts on viticulture and wine making. Some authors have evidenced that yield is more or less a linear function of temperature in quite a wide range of temperatures, but above a certain threshold -which value depends on different parameters such as humidity, soil composition, etc.- it starts to show decreasing rates and then declines, making viticulture no more profitable (Wood ad Anderson 2006). Hence, global warming is pushing vine cultivation northwards and to higher elevations, while it is making difficult and more costly, if not impossible, to grow grapes in lower southern and more arid traditionally producing areas. As a consequence of climate change, there are winners and losers in the wine sector (Storchmann 2012). Somewhere, higher temperatures positively impact grape and wine quality and, this, in turn, raises consumers' willingness to pay and, hence, raises prices (Jones et al. 2005). However, even within the same area, climate change allows and sometimes imposes different grape varieties to be grown and this usually have a deep impact on the production technology (both in the vineyard and in the winery), on production costs and on product quality. All this implies that only firms that are able to engage with technological change and to repositioning in the market while investing in rebuilding/restyling their reputation can survive in the new conditions. Clearly enough, there is also a collective dimension of the adaptation to the new climate conditions. This means that it is also relevant to analyze the impact of climate change at local and regional level. In fact, effective reactions to these changes are, in some cases, not only at the firm level but mainly at the level of the supply chain or of the local production system/cluster (Galbreath et al. 2016). Such changes and shifts in production have many implications under different respects. The most explored in economic literature are linked to technological change, to the impact on cost level and structure and to the necessity for newcomers to overcome entry barriers and specifically to build their own reputation in markets where product names — at the country, region, and firm level—do make a difference.

Innovation is not only related to climate change, but it is also a response of dynamic producers and of producing systems to the increasing demand for quality, to rapidly transforming consumers' preferences and to the fast changes in the world competitive arena. In this sense, causes and consequences of technological change in terms of efficiency and competitiveness at the firm, supply chain and country level, are explored in one more stream of wine literature (Giuliani et al. 2011).

As wine cooperatives are quite common in many countries, two major issues in coop functioning are often explored in wine economics. Both are related to the provision of quality as this is often one of their major drawbacks. First, contractual relationships between the cooperative and its members are plagued by moral hazard issues and adverse selection problems that endanger grape quality. Different incentive schemes and deterrent systems are studied (M'Hand 2014). Second, because of this core internal problem, coops face difficulties in catching-up with quality in a market that, as already discussed, is every day more demanding in terms of product 
quality, variety and choice. Hence, whether coops can successfully establish their own reputation, and compete with private wineries in the marketplace and under what conditions, remain an open question (Schamel 2015).

\section{Public regulation}

The wine sector has historically been subject to extensive public control and strict administration policies including production subsidies, price guarantees and market stabilizers, but also, in different time periods, different kind of constraints and production limitations such as plantation restrictions and explantation premia (Meloni et al. 2019). Hence, it is not surprising that a great deal of attention in the field of economic studies has been devoted to the analysis of such policies and of their impacts on producers, consumers and trade, together with their consequences in terms of general welfare, public budget and taxpayers. At the same time, the tensions arising among different groups of stakeholders with diverging interests became paramount and paradigmatic of the sector (Meloni et al. 2019). Especially the EU wine policy-developed along many decades within the framework of the Common Agricultural Policy (CAP) — has been studied for long and compared to different policy approaches (i.e. the US), both with respect to market interventions and structural measures. The EU wine policy was born in the expansive and generous phase of the first CAP that basically sustained farmers income through market interventions that assured high prices. Over time, this policy created deep imbalances with excess supply in a contest of reducing per capita consumption and limited export possibilities. Afterwards, the CAP changed towards the search of a better market equilibrium through supply control while demand continued to decrease rapidly while consumers switched towards higher quality wines. The goal of rebalancing the market has been pursued in the frame of significant constraints posed by the need to sustain farmers' revenues. The main instruments adopted were premiums for explanting vines and severe limitations to plant new vineyards. One side effect of these measures has been to alter deeply the demographic equilibrium of plantations with a dramatic increase of the share of very old plantations that have long lasting effects on the future vitality of the sector (Carbone et al. 2019). After undergoing a long and difficult reform policy -that, together with the general CAP, led to a more liberalized primary sector-more recently the EU wine policy encompasses environmental as well as social goals. These imply the introduction of restrictions on the cultivation techniques (i.e. use of pesticides) and consumers' protection measures (i.e. wine labelling regulation) (Pomarici and Sardone 2020).

Wine policies are frequent also on the demand side. In fact, in many countries also consumption is subject to restrictions and taxation due to the health effects of alcohol both on long and on the short-term. Taxation varies greatly in kind and incidence: there are countries that impose more than $100 \%$ taxes and countries with almost $0 \%$ taxes on alcoholic beverages. However, alcohol taxation shows a generalized tendency to rise in recent times. Tax types also differ widely from high VAT rates to specific ad hoc alcohol taxes. These differences are explained with different arguments such as traditions, different degrees of public health concerns, different 
lobbying capacities of stakeholders (Anderson 2020; Corsinovi 2021). Besides, and in connection with the goals of the wine fiscal policies, some country opted for operating the retail sector by a State monopoly that seeks at a stricter control of consumption. Effects on consumption and on general welfare of these monopolies are discussed in different papers (Lai et al 2013; Dahlström, and Åsberg 2009; Wagenaar and Holder 1995).

Furthermore, as wine is basically an experience good that embeds also some credence attributes (i.e. product origin, the presence of additives, whether is organically produced, etc.) information asymmetries arise and may cause moral hazard and free riding behaviors in the marketplace as well as along the supply chain. Studies on the information asymmetries affecting the market look both at the demand and at the supply side (Saïdi et al. 2020; Anania and Nisticò 2004; Onur et al. 2020; Giraud et al. 2011). These also include a vast number of papers centered on the political economy of geographical Indications and of producers' branding and labelling strategies. The two milestone contributions on which this rich strand of literature bases are: (i) Tirole's "A theory of collective reputations (with applications to the persistence of corruption and to firm quality)" (Tirole 1996), that highlights the intrinsic collective dimension of reputation at every level; (ii) Josling's "What's in a name. The economics, law and politics of Geographical Indications for foods and beverages" (Josling 2006), that bases the political economy for analyzing Geographical Indications. This essay focuses on the trade-off between lowering transaction costs through the international harmonization of national systems, on the one side, and tailoring national GI law on domestic needs and traditions, on the other side. It also explores the extent to which global goods are created when multilateral coordination replaces national administration of GI regulation. ${ }^{3}$

Anania and Nisticò also contributed to this body of literature with the article "Public regulation as a substitute for trust in quality food markets: what if the trust substitute cannot be fully trusted?" (2004) where they trace the bases for subsequent analysis of the effectiveness of public regulation on Geographical Indications when the public regulation is not perfectly designed and there is room for free riding behaviors of producers that undermine trust in the quality certification scheme.

\section{Concluding Remarks}

In concluding this short review, it is worthwhile trying to trace the most likely topics with which future research will engage. One recently emerging feature also for the wine sector is the rise of global value chains as a worldwide organization mode of supply. Despite wine production is only weakly segmentable if not at all, global companies affirmed their role as traders and retailers but also in the role of producers and packers thanks to relevant multinational investment campaigns. As a result, the wine sector will probably be increasingly polarized between a small group of huge leading groups -who benefit from low costs and financial advantages, significant

\footnotetext{
3 See also Alston and Gaeta (2021).
} 
flexibility, and widely established reputation- and a large number of small and very small producers -who can benefit from product diversification, deep roots in the terroir and a strong identity related to traditions. There is still much room for analyzing factors pushing towards one pole or the other one. Also, one emerging issue that calls for further analysis, strictly connected with the previous one, is the increasing role of e-commerce in the wine sector. On-line shopping encompasses both small producers and larger retailers operating at a global scale, however, it can be argued that the largest impact is potentially on small producers who, thanks to the shortened chain, increase their visibility in the final consumer market and are able to capture a major share of the value added.

Besides other major changes, the recent COVID-19 pandemic is having a deep influence on buying and consuming behaviors in the food sector as well as for wine. On-line shopping boosted as well as home consumption. With stringent limits to social life, wine reduced its role of good for social occasions. Hence, there is much role for reflections on the consequences that these changes will have on consumer choice and willingness to pay for wine.

The pandemic seems to have had an impact also on citizens' perception of environmental issues. This may also reflect on consumers' preferences about wine. For example, many wine environmental certifications that so far remained small market niches may attract more consumers. Thus, there will be the need to understand in which countries, to what extent and under which conditions, wine demand will shift towards eco-friendly produced wines.

In the meanwhile, policies will continue to change, and the effects of these changes will require continuous analysis. At the EU level, the liberalization process of the sector is traced but not yet completed nor its effects are yet over and need further assessments. Last, but not least, the ever changing geography of trade wars and of trade agreements will continue to fuel economic research devoted to the wine sector as this product is often marketed with different kinds of geographical Indications that are far of being all mutually recognized by the major trade players.

\section{References}

Alston J, Gaeta DN (2021) Reflections on the political economy of the European wine appellations. Ital Econ J.

Anania G, Nisticò R (2004) Public regulation as a substitute for trust in quality food markets: what if the trust substitute cannot be fully trusted? J Inst Theor Econ 160(4):681-701

Anderson K (2020) Consumer taxes on alcohol: an international comparison over time. J Wine Econ 15(1):42-70

Ashenfelter O, Ashmore D, Lalonde R (1995) Bordeaux wine vintage quality and the weather. Chance $8(4): 7-14$

Bargain O, Cardebat JM, Chiappini R, Laffitte C (2018) Long-term prospects of the international wine trade. J Wine Econ 13(4):442-450

Cacchiarelli L, Carbone A, Esti M, Laureti T, Sorrentino A (2016) Assessing Italian wine quality and prices: de gustibus non disputandum est. Br Food J 118(5): 1006-1024

Calvo-Porral C, Lévy-Mangin JP, Ruiz-Vega A (2020) An emotion-based typology of wine consumers. Food Qual Prefer 79:103777

Caracciolo F, Cembalo L, Pomarici E (2013) The hedonic price for an Italian grape variety. Ital J Food Sci 25(3):289 
Carbone A, Cacchiarelli L, Laureti T, Sorrentino A (2014) The value of quality clues in the wine market. Evidences from Lazio, Italy. J Wine Res 25(4): 281-297.

Carbone A, Quici L, Pica G (2019) The age dynamics of vineyards: past trends affecting the future. Wine Econ Policy 8(1):38-48

Carbone A, Demaria F, Henke R (2021) The sophistication of international wine trade: a new import measure. Ital Econ J 7(2).

Carlsen J, Boksberger P (2015) Enhancing consumer value in wine tourism. J Hos Tour Res 39(1):132-144

Charters S, Pettigrew S (2008) Why do people drink wine? A consumer-focused exploration. J Food Prod Market 14(3):13-32

Combris P, Lecocq S, Visser M (1997) Estimation of a hedonic price equation for Bordeaux wine: does quality matter? Econ J 107(441):390-402

Corsinovi P (2021) Consumer taxes on alcohol: is the wine sector a niche within the alcoholic beverages? Ital Econ $\mathrm{J} 7(2)$

Costanigro M, McCluskey JJ, Mittelhammer RC (2007) Segmenting the wine market based on price: hedonic regression when different prices mean different products. J Agric Econ 58(3):454-466

Dahlström T, Åsberg E (2009). Determinants of demand for wine-price sensitivity and perceived quality in a monopoly setting (No. 182). In: Royal Institute of Technology, CESIS-Centre of Excellence for Science and Innovation Studies.

Danner L, Ristic R, Johnson TE, Meiselman HL, Hoek AC, Jeffery DW, Bastian SE (2016) Context and wine quality effects on consumers' mood, emotions, liking and willingness to pay for Australian Shiraz wines. Food Res Int 89:254-265

Folwell RJ, Volanti M (2003) The changing market structure of the USA wine industry. J Wine Res 14(1):25-30

Galati A, Crescimanno M, Coelho A, Maizza A (2020) Recent trends in the wine consumers' behaviour and need for effective marketing strategies. Br Food J 122(8):2361-2753

Galbreath J, Charles D, Oczkowski E (2016) The drivers of climate change innovations: evidence from the Australian wine industry. J Bus Ethics 135(2):217-231

Giraud G, Tebby C, Amblard C (2011) Measurement of consumers' wine-related knowledge. Enometrica 4(1):33-42

Giuliani E, Morrison A, Rabellotti R (eds) (2011) Innovation and technological catch-up: the changing geography of wine production. Edward Elgar Publishing, UK

Gwynne RN (2008) UK retail concentration, Chilean wine producers and value chains. Geogr J 174(2):97-108

Hall J, Binney W, OMahony GG (2004) Age related motivational segmentation of wine consumption in a hospitality setting. Int J Wine Market 16(3):29-44

Hommerberg C (2011) Persuasiveness in the discourse of wine: the rhetoric of Robert Parker (Doctoral dissertation, Linnaeus University Press).

Josling TE (2006) What's in a Name? The economics, law and politics of Geographical Indications for foods and beverages. International Institute for Integration Studies Discussion Paper No. 109, 1-30

Lai MB, Cavicchi A, Rickertsen K, Corsi AM, Casini L (2013) Monopoly and wine: the Norwegian case. Br Food J 115(2):314-326

Lesschaeve I (2007) Sensory evaluation of wine and commercial realities: review of current practices and perspectives. Am J Enol Vitic 58(2):252-258

Mariani A, Pomarici E, Boatto V (2012) The international wine trade: recent trends and critical issues. Wine Econ Policy 1(1):24-40

Masset P, Henderson C (2010) Wine as an alternative asset class. J Wine Econ 5(1):87-118

Meloni G, Anderson K, Deconinck K, Swinnen J (2019) Wine regulations. Appl Econ Perspect Policy 41(4):620-649

Mouret M, Monaco GL, Urdapilleta I, Parr WV (2013) Social representations of wine and culture: a comparison between France and New Zealand. Food Qual Prefer 30(2):102-107

Nerlove M (1995) Hedonic price functions and the measurement of preferences: the case of Swedish wine consumers. Eur Econ Rev 39(9):1697-1716

Oczkowski E (1994) A hedonic price function for Australian premium table wine. Aust J Agric Econ 38(1):93-110

Onur I, Bruwer J, Lockshin L (2020) Reducing information asymmetry in the auctioning of non-perishable experience goods: the case of online wine auctions. J Retail Consum Serv 54:102060 
Pelegrín-Borondo J, Olarte-Pascual C, Oruezabala G (2020) Wine tourism and purchase intention: a measure of emotions according to the PANAS scale. J Wine Res 31(2):101-123

Pomarici E, Sardone R (2020) EU wine policy in the framework of the CAP: post-2020 challenges. Agric Food Econ 8(1):1-40

Pomarici E, Corsi A, Mazarino S, Sardone R (2021) The Italian wine sector: evolution, structure, competitiveness and future challenges of an enduring leader. Ital Econ J 7(2).

Ponte S, Ewert J (2009) Which way is "up" in upgrading? Trajectories of change in the value chain for South African wine. World Dev 37(10):1637-1650

Romano D, Rocchi B, Sadiddin A, Stefani G, Zucaro R, Manganiello V (2021) A SAM-based analysis of the economic impact of frauds in the Italian wine value chain. Ital Econ J

Rosen S (1974) Hedonic prices and implicit markets: product differentiation in pure competition. J Polit Econ 82(1):34-55

Saïdi M, Ay JS, Marette S, Martin C (2020) Willingness-to-pay for reshuffling geographical indications. J Wine Econ 15(1):95-111

Schamel G (2015) Can German wine cooperatives compete on quality? In: BIO Web of Conferences 5: 03003. EDP Sciences.

Schamel G, Ros A (2021) Indicators of individual wine reputation for Friuli Venezia Giulia. Ital Econ J $7(2)$.

Sherman S, Tuten T (2011) Message on a bottle: the wine label's influence. Int J Wine Bus Res 23(3):221-234

Storchmann K (2012) Wine economics. J Wine Econ 7(1):1-33

Thach L (2012) Time for wine? Identifying differences in wine-drinking occasions for male and female wine consumers. J Wine Res 23(2):134-154

Tirole J (1996) A theory of collective reputations (with applications to the persistence of corruption and to firm quality). Rev Econ Stud 63(1):1-22

Unwin T (1999) Hedonic price indexes and the qualities of wines. J Wine Res 10(2):95-104

Unwin T (2005) Wine and the vine: an historical geography of viticulture and the wine trade. Routledge, London 